the affectionless mother. Therapists may tend to stress postnatal factors as they feel that they are more modifiable.

Modifications of the original nine types of maladjustment first described in the Bristol Social Adjustment Guides are included. There is added a syndrome of inconsequence. Many so-called psychopaths or conscienceless children would have this syndrome; they live in the present and their behaviour does not seem to be modified by past experience or future events.

In the final chapter Dr. Stott gives his own theory of human behaviour and motivation. In each of us there is "an appraisal-response system" which scans the environment for what is suitable or unsuitable. No entity is at the source of motivation except a neural structure, and impaired behaviour is often the result of self-protective dysfunctioning of the appraisal system.

There is little reference to any positive contribution made by psychiatrists, though very severe cases might be referred to a child guidance clinic. There is a shortage of psychiatrists and psychologists trained to work with young children, and it may be this which leads Dr. Stott to emphasize the importance of an enlarged school welfare service. It is, however, doubtful whether sufficient adequately trained welfare officers are available. Possibly this book makes the problem of delinquency seern almost too simple, and suggestions such as "if the home is unmodifiable the boy should go to a voluntary approved school so that the parents' affection has a chance to revive" sidesteps the very many difficulties that are likely to occur when the boy returns home if nothing has been done to help the parents.

This book is provocative, deliberately so, and can be recommended to school medical officers, teachers, educational welfare officers and all concerned with the social misdemeanours of children.

R. F. Barbour

\section{MAN, PAST AND PRESENT}

\section{Origins of Man: Physical Anthropology}

By John Beuttner-Janusch. Pp. xxvii +674. (New York and London: John Wiley and Sons, Ltd., 1966.) $72 s$.

Professor Bedtriner-Janusch's volume is in many respects better than most of the text-books on physical anthropology used in undergraduate courses at American universities. His book is well balanced, well planned, and up to date. It has plenty of technical detail, but is not over demanding. The material is presented in the usual two sub-divisions of the subject-man in the past and man in the present.

The first half deals comprehensively with man's primate affinities, and with pre-hominid and hominid evolution. As an introduction to this section are the basic evolutionary concepts of natural selection, mutation, adaptive radiation, parallelism and convergence, irreversibility and extinction. These are clearly explained in simple, non-quantitative fashion. Some of the problems of taxonomy are discussod and guidance given on the designation of species and higher categories. Attention is commendably drawn to the usages of the International Code of Zoological Nomenclature, but quite insufficient warning is given against the practice of excessive, premature and unwarranted naming that goes on among primate palaeontologists. The safoguard against this-the proper understanding of affinity and the statistical methods for its evaluation-should have been given prominence and worked examples presented.

Tho remainder of this first section is made up of straightforward descriptions of the various primate families and genera leading to a consideration of the more important fossil evidence bearing on hominid evolution. There is a useful section on the material-bones, teeth and musclethat has to be handled in evolutionary and comparative studies, but this would obviously need to be supplemented by practical classwork.

In the second half of the book the author approaches the study of living man essentially from the point of view of the analysis of population variation. Here the author develops the notions of selection, fitness, mutation, genetic drift and hybridization in a more analytic and quantitative fashion, as appropriate data are, of course, available for living populations; the book scores in its substantial but judicious presentation of basic genetic information on man and other primates-on chromosome morphology, on the blood group systems, the haemoglobins and the serum proteins.

I would have wished to see a rather more ecological analysis of contemporary populations, human and subhuman, but perhaps this topic is properly reserved for more advanced courses in human biology.

\section{J. S. WEINER}

\section{DEVELOPMENT}

\section{Cell Differentiation and Morphogenesis}

By W. Beorman, R. J. Gautheret, P. D. Nieuwkoop, C. W. Wardlaw, V. B. Wigglesworth, E. Wolff and J. A. D. Zeevaart. (International Lecture Course, Wageningen, The Netherlands, April 26-29, 1965.) Pp. viii +209. (Amsterdam: North-Holland Publishing Company, 1966.) 30 guilders; 60s.; $\$ 8.40$.

E. WOLFF's general introduction to this book could, apart from a potted account of gene transcription, translation and regulation, equally well have been written thirty years ago. It is, moreover, carelessly written (or translated) (for example, "gurdle" for "girdle", and the use of such words as "glomerules", "plurilayered", "villosities", "organisator") and it is odd to find no reference to Waddington's early work in an exposition largely concerned with induction and competence.

This disappointing opening is followed by Beerman's excellent summary of recent work on the behaviour and function of Balbiani rings in relation to the transcription process and the regulation of protein synthesis, and then by two lectures on plant development. That by R. J. Gautheret is a useful account of the effects of growth substances, glucose, light and cell interrelationships on root, bud and flower formation in tissue cultures; the other, by C. W. Wardlaw, is also concerned with metabolic and specific growth substances, and the importance of positional relationships and metabolic differences leading to differential growth. Wardlaw's statement that ". ... a phasic, or sequential synthesis of different proteins... with concomitant differential metakolism in tissues . . . could afford a basis for the eventual morphological differences between organs" calls to mind what Paul Weiss said fourteen years ago, ". . . just how to get from chemical activity to highly specific cytological and histological structure and architecture, is not only unknown, but rarely even stated explicitly as a pressing problem". His comments on "leaf" and "bud" proteins are inter. esting to a zoologist, and remind one of the work on "vegetalizing" and "animalizing" proteins in Echinoderms.

Nieuwkoop's article on induction and pattern formation in animals is particularly clear and useful. It is the only one in the book in which such biophysical phenomena as selective adhesiveness are discussed. Zeevaart's discussion of hormonal regulation in plant development is, however, somewhat heavy going, and in parts naive. He seems to imply that the problem of development would be solved if we knew how genes were regulated. This is far from the truth, and is rather like saying that one would know how a bridge was built if one knew how steel was made ! 